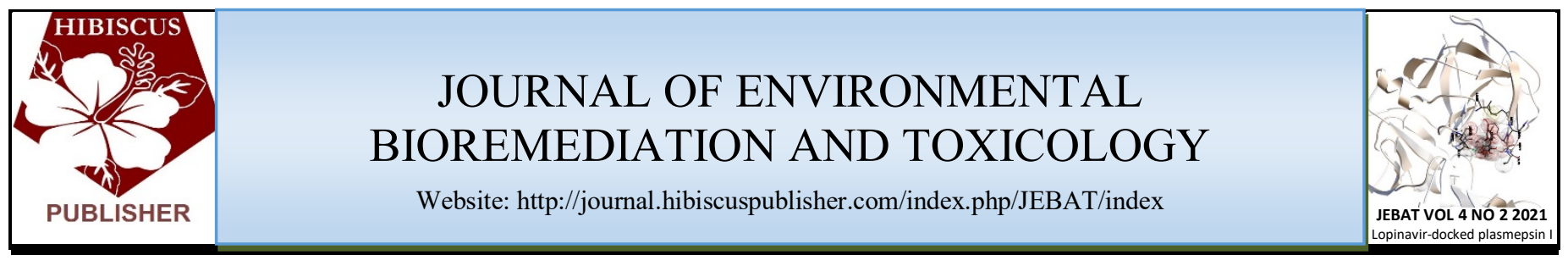

\title{
Distribution of Heterotrophic and Nitrogen fixing Rhizobacteria in Irrigation Sites of Lake Alau Borno State Northeastern Nigeria
}

\author{
Ibrahim Alkali Allamin ${ }^{1 *}$, Hussaini Shettima ${ }^{1}$ Hafsat Muhammad Abdullahi ${ }^{1}$, Usman Ali Bukar ${ }^{1}$ Amina Umar \\ Faruk $^{1}$ and Abdulhamid Musa Ruwa ${ }^{1}$
}

${ }^{1}$ Department of Microbiology, Faculty of Science, University of Maiduguri P.M.B 1069, Maiduguri, Nigeria.

\author{
*Corresponding author: \\ Dr. Ibrahim Alkali Allamin, \\ Department of Microbiology, \\ Faculty of Science, \\ University of Maiduguri, \\ P.M.B 1069 \\ Maiduguri, \\ Nigeria. \\ Email: ibnallamin@gmail.com
}

\section{HISTORY \\ Received: $23^{\text {rd }}$ Aug 2021 \\ Received in revised form: $24^{\text {th }}$ Oct 202 Accepted: $12^{\text {th }}$ Nov 2021}

\section{KEYWORDS}

\section{Rhizobacteria} Agriculture

Plant Growth Promoting Rhizobacteria PGPR Total heterotrophic bacteria Irrigation and non-irrigation

\begin{abstract}
This study was conducted to know the population of rhizobacteria in both irrigation and nonirrigation sites of the dam. The dense population of these organism indirectly promote plant growth and development. Five sites (A, B, C, D and E) were used to collect soil samples randomly and transported to the laboratory for analysis. Total heterotrophic bacterial count was done using nutrient agar (NA) and nitrogen fixing bacteria was counted using Ashbey's media (AM). The result shows that highest number of total heterotrophic bacteria in site $C\left(46.0 \times 10^{6}\right) \mathrm{cfu} / \mathrm{g}$ in irrigation site whereas higher count in non-irrigation site was $\left(13.0 \times 10^{6}\right)$ site $\mathrm{D}$, the nitrogen fixing bacterial count in irrigation site was higher at site E with $\left(12.0 \times 10^{6}\right)$ and for the nonirrigation site was higher at site D with $\left(14.0 \times 10^{6}\right)$ The total heterotrophic bacteria isolated in the soil sample are the species of Bacillus alvei, Bacillus alvei, Bacillus cereus, Bacillus cereus, Pseudomonas putida, Klebsiella aeruginosa and Enterobacter aeruginosa. Likewise, the Nitrogen fixing bacteria isolated are the species of Rhizobium leguminosarum, Klebsiella pneumonia, Bacillus lentus, Azotobacter nigricans, Azotobacter tropicalis, Azotobacter spp, and Azotobacter tropicalis. The long history of agricultural activities in the lake area has directly influenced the diversity of microbial population in the area.
\end{abstract}

\section{INTRODUCTION}

It is fairly uncommon to hear the term "rhizobacteria that promote plant growth" used to describe rhizobacteria (PGPRs). [1] Joseph W. Kloepper initially introduced the word, and it has since become a widespread term in scientific literature. Various species of host plants have different PGPR interactions. Rhizospheric and endophytic connections are the two types. The PGPRs that colonise the surface of the root or the superficial intercellular spaces of the host plant, typically creating root nodules [2], create rhizospoheric interactions. [3] PGPR are bacteria that infiltrate plant roots to enhance plant development and/or to decrease disease or insect damage. There has been a lot of interest in PGPR, and there are now more PGPR crops on the market. Biochemical nitrogen fixation, increased availability of nutrients, root surface area expansion, and other beneficial symbiosis enhancement are only some of the ways PGPR improves nutritional status in host plants [1-3].
Research has shown that many plant-associated bacteria, especially from the rhizosphere, are beneficial to plant development, yield, and crop quality. Numerous more species of Aeromonads and Azoarcus, Azospirillae and Azospirillum, Azotobacteria and Pseudomonas have been identified as PGPR, and the hunt for new ones continues [4]. Bacillus and Closporium strains have also been identified as PGPR [3, 4]. The poor yield and production of plant worldwide is considered a great challenged. The performance of plants is greatly enhanced by rhizobacteria distribution in the soil. The need to determine the distribution of rhizobacteria cannot be overemphasized. The objective of this study is, therefore, to know the distribution of rhizobacteria in irrigation and non-irrigation farms around Lake Alau, Maiduguri Nigeria.

\section{MATERIALS AND METHODS}

\section{Study Area}

Located between latitude $1104 \mathrm{~N}$ and $1205 \mathrm{~N}$ and longitude $1305 \mathrm{E}$ and 130E, Alau Dam in Alau village is situated in Konduga, Borno State, Nigeria. The dam is 9 metres high and has a 50 - 
square-mile reservoir. Capacity is limited to 112 million metre cubes. River Yedzram and River Gombole, which merge near Sambisa and flow as River Ngadda into Alau Dam, provided Alau Dam with water. A vast range of agricultural wastes was deposited in Alau Dam. Commercial fishing is also common on this lake. Alau has a total population of 6895, with 1174 total homes (Planning unit Konduga LGA secretariat).

\section{Sample collection}

Rhizosphere soils for microbiological analyses were collected by gently and carefully shaking of an up rotted plant into sterile polythene bags [5]. For the non- rhizosphere analysis however, the soil surrounding the up-rotted plant was sampled at a depth of 1 to $10 \mathrm{~cm}$ into sterile polythene bags using auger. The soil was sampled at random in duplicates. Representative samples were obtained bulked and transported to the laboratory in polythene bags for analysis [6].

\section{Microbiological analysis of the soil samples \\ Enumeration of total aerobic heterotrophic and nitrogen fixing bacteria}

Microorganisms adhering to the soil particles were dislodged by shaking the test tube violently with $9 \mathrm{ml}$ of distilled water for one gramme of each sample, which was weighed aseptically. From $10^{1}$ to $10^{7}$, the tube's contents were serially diluted. Total aerobic heterotrophic bacteria and nitrogen-fixing bacteria were counted using dilutions $\left(10^{-7}\right)$ and $\left(10^{-5}\right)$ in triplicate on sterile Nutrient agar (NA) and Ashbay's Media (AM). For 48 hours, the plates were kept at ambient temperature $\left(30 \pm 2^{\circ} \mathrm{C}\right)$. It was determined how many colony-forming units per gramme of soil ( $\mathrm{cfu} / \mathrm{g}$ ) the plates produced by counting the colonies that formed there. Repeated sub-culturing of the isolates on the medium used for initial isolation resulted in the production of pure cultures. They kept the isolated samples for further study and identification on agar plates [6]

\section{Characterization and Identification of Isolates}

Pure isolates of bacteria were identified based on colonial, morphological and biochemical characteristics following the guidelines outlined by Prescott and Harley[7].

\section{RESULTS AND DISCUSSIONS}

The results of this study shows that total heterotrophic bacterial count is higher in irrigation site of the dam with $\left(46.0 \times 10^{6}\right) \mathrm{cfu} / \mathrm{g}$ in site $\mathrm{C}$ to as low as $\left(12.0 \times 10^{6}\right) \mathrm{cfu} / \mathrm{g}$ in site E. Likewise in the non- irrigation site it show a higher count of $\left(13.0 \times 10^{6}\right) \mathrm{cfu} / \mathrm{g}$ in site $\mathrm{D}$ and low count of $\left(11.0 \times 10^{6}\right) \mathrm{cfu} / \mathrm{g}$ in site A.It's possible for PGPR to colonise the rhizosphere, the root surface, or even the intercellular gaps between cells in the irrigation site soil $[8,9]$. These locations are inhospitable to any kind of soil bacteria. Soil composition of the rhizosphere is altered by the plant, as opposed to the non-irrigated bulk soil, and this may have an impact on the capacity of the PGPR to colonise the rhizosphere [1]. Nitrogen fixing bacterial count also shows a higher count of $\left(12.0 \times 10^{6}\right)$ $\mathrm{cfu} / \mathrm{g}$ at site $\mathrm{E}$ and a lower count of $\left(77.0 \times 10^{7}\right) \mathrm{cfu} / \mathrm{g}$ at site $\mathrm{D}$ in the irrigation sites while the non- irrigation site had a higher counts $\left(14.0 \times 10^{7}\right) \mathrm{cfu} / \mathrm{g}$ at site $\mathrm{D}$ and lower count of $\left(10.0 \times 10^{7}\right)$ $\mathrm{cfu} / \mathrm{g}$ at site E. Likewise the infection process and development of Nitrogen-fixing specialized species will be higher in the irrigation site to that of non-irrigation sites because of the growth of plant with symbiotic relationship with nitrogen fixing bacteria in that site [1,8] Figs. 1 and 2.
The total heterotrophic bacteria isolated in the soil sample are the species of Bacillus alvei, Bacillus alvei, Bacillus cereus, Bacillus cereus, Pseudomonas putida, Klebsiella aerogenes and Enterobacter aeruginosa [4] also isolated some of these species. Likewise, the Nitrogen fixing bacteria isolated are the species of Rhizobium leguminosarum, Klebsiella pneumonia, Bacillus lentus, Azotobacter nigricans, Azotobacter tropicalis, Azotobacter spp, and Azotobacter tropicalis. The biodiversity in rhizosphere soil is always rich of plant growth promoting bacteria.

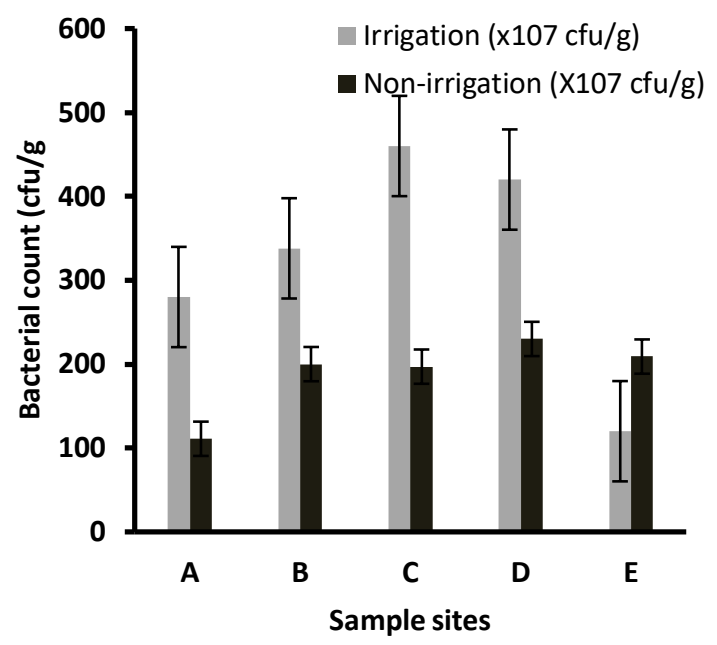

Fig. 1. Distribution of rhizobacteria in irrigation and non-irrigation sites

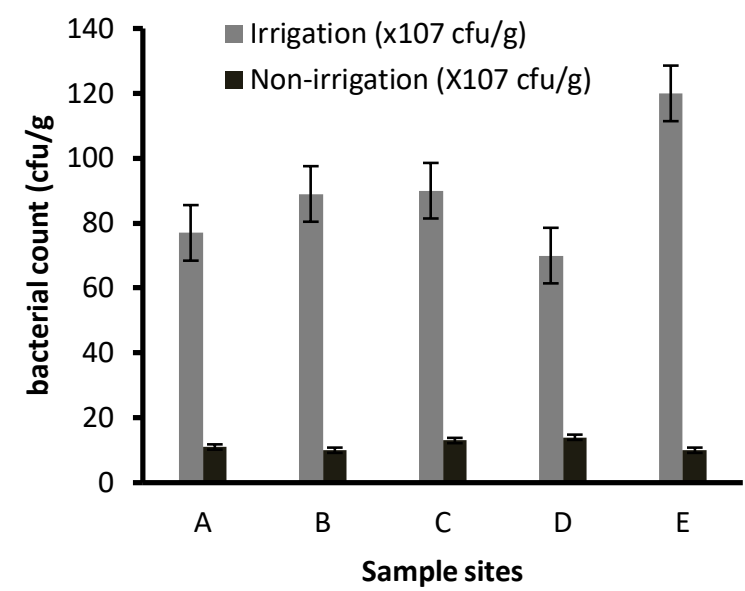

Fig. 2. Distribution of nitrogen fixing rhizobacteria in irrigation and nonirrigation sites.

Plant development is stimulated by a wide variety of soil bacteria that thrive in the rhizosphere of plants, but which may also grow on, around, or inside plant tissues. PGPR refers to a group of microorganisms (plant growth promoting rhizobacteria). Research into the mechanisms of action of PGPR is developing rapidly as attempts are made to commercialise its use as biofertilizers. 
Table 1: Characterization and identification of total heterotrophic bacteria.

\begin{tabular}{|c|c|c|c|c|c|c|c|c|c|c|c|c|c|c|c|c|c|c|}
\hline \multirow[t]{3}{*}{ Isolate } & \multicolumn{3}{|c|}{ Staining } & \multicolumn{14}{|c|}{ Biochemical Characteristics } & \multirow[t]{3}{*}{ Identified Species } \\
\hline & \multirow[t]{2}{*}{ GR } & \multirow{2}{*}{\multicolumn{2}{|c|}{ Shape Spore }} & \multirow[t]{2}{*}{$\mathrm{COA}$} & \multirow[t]{2}{*}{ CAT } & \multirow{2}{*}{\multicolumn{2}{|c|}{ OXI MR }} & \multirow[t]{2}{*}{ VP } & \multirow[t]{2}{*}{ UR } & \multirow[t]{2}{*}{ IND } & \multirow[t]{2}{*}{ CIT } & \multicolumn{6}{|c|}{ TSI } & \\
\hline & & & & & & & & & & & & $\overline{\mathrm{GLU}}$ & LAC & SUC & $\mathrm{H}_{2} \mathrm{~S}$ & GAS & MOT & \\
\hline A11 & + & SR & + & NA & + & + & - & + & + & + & - & + & + & + & - & - & + & Bacillus alvei \\
\hline A12 & + & $\mathrm{CC}$ & - & - & + & - & - & - & - & - & + & + & + & + & + & - & - & $\begin{array}{l}\text { Staphylococcus } \\
\text { warneri }\end{array}$ \\
\hline B13 & - & SR & - & NA & + & - & - & + & - & - & - & + & + & + & - & - & - & $\begin{array}{l}\text { Actinobacillus } \\
\text { succinigenes }\end{array}$ \\
\hline B21 & - & SR & - & NA & + & - & - & + & + & - & + & + & - & - & - & - & + & $\begin{array}{l}\text { Pseudomonas } \\
\text { putida }\end{array}$ \\
\hline $\mathrm{C} 22$ & - & SR & - & NA & + & - & + & - & + & - & + & + & - & - & - & - & - & $\begin{array}{l}\text { Klebsiella } \\
\text { aerogenes }\end{array}$ \\
\hline C33 & - & SR & - & NA & + & - & + & + & + & - & - & + & + & + & - & - & + & $\begin{array}{l}\text { Enterobacter } \\
\text { aeruginosa }\end{array}$ \\
\hline D14 & + & SR & + & NA & + & + & - & + & + & + & - & + & + & + & - & - & + & Bacillus alvei \\
\hline D11 & + & LR & + & NA & + & - & - & + & + & + & + & + & - & - & + & + & + & Bacillus cereus \\
\hline E22 & + & LR & + & NA & + & - & - & + & + & + & + & + & - & - & + & + & + & Bacillus cereus \\
\hline
\end{tabular}

KEY: GR- Gram Reaction, COA- Coagulase, CAT- Catalase, OXI- Oxidase, MR- Methyl Red, VP- Voges-Proskauer, IND- Indole, CIT- Citrate, TSI- Triple Sugar Iron, GLU- Glucose, LAC- Lactose, SUC- Sucrose, $\mathrm{H}_{2} \mathrm{~S}$ - Hydrogen Sulphide, GAS- Gas Production, MOT- Motility, SR- Short Rod, LR (shape)- Long Rod, CC- Cocci Clusters, CP- Cocci Pairs, NA Not Applicable

Table 2: Characterization and identification of Nitrogen fixing bacterial species.

\begin{tabular}{|c|c|c|c|c|c|c|c|c|c|c|c|c|c|c|c|c|c|c|}
\hline \multirow[t]{3}{*}{ Isolate } & \multicolumn{4}{|c|}{ Staining } & \multicolumn{13}{|c|}{ Biochemical Characteristics } & \multirow[t]{3}{*}{ Identified Species } \\
\hline & \multirow[t]{2}{*}{ GR } & \multirow[t]{2}{*}{ Shape } & \multirow[t]{2}{*}{ Spore } & \multirow[t]{2}{*}{ Cyst } & \multirow[t]{2}{*}{ CAT } & \multirow[t]{2}{*}{ OXI } & \multirow[t]{2}{*}{ MR } & \multirow[t]{2}{*}{ VP } & \multirow[t]{2}{*}{ UR } & \multirow[t]{2}{*}{ IND } & \multirow{2}{*}{ CIT } & \multicolumn{6}{|c|}{ TSI } & \\
\hline & & & & & & & & & & & & GLU & LAC & SUC & $\mathrm{H}_{2} \mathrm{~S}$ & GAS & MOT & \\
\hline A12 & - & SR & - & - & + & + & - & - & + & - & - & + & - & - & - & - & + & $\begin{array}{l}\text { Rhizobium } \\
\text { leguminosarum }\end{array}$ \\
\hline A23 & - & SR & - & - & - & - & - & + & + & + & - & + & - & - & - & - & - & Klebsiella pneumoniae \\
\hline B14 & + & $\mathrm{R}$ & + & - & - & + & - & - & + & + & + & + & - & - & + & - & + & Bacillus lentus \\
\hline LR05 & - & SR & - & + & + & + & - & - & + & + & + & - & - & - & - & - & - & Azotobacter nigricans \\
\hline LR06 & - & SR & - & + & + & + & - & - & + & + & + & - & - & - & - & - & + & Azotobacter tropicalis \\
\hline LU01 & - & SR & - & + & + & + & - & - & + & - & + & - & - & - & - & - & + & Azotobacter spp \\
\hline LU02 & - & SR & - & + & + & + & - & - & + & + & + & - & - & - & - & - & + & Azotobacter tropicalis \\
\hline LU03 & - & SR & - & - & + & + & - & - & + & - & - & + & - & - & - & - & + & $\begin{array}{l}\text { Rhizobium } \\
\text { leguminosarum }\end{array}$ \\
\hline LU04 & - & SR & - & - & + & + & - & - & + & - & - & + & - & - & - & - & + & $\begin{array}{l}\text { Rhizobium } \\
\text { leguminosarum }\end{array}$ \\
\hline
\end{tabular}

KEY: GR- Gram Reaction, COA- Coagulase, CAT- Catalase, OXI- Oxidase, MR- Methyl Red, VP- Voges-Proskauer, IND- Indole, CIT- Citrate, TSI- Triple Sugar Iron, GLU- Glucose, LAC- Lactose, SUC- Sucrose, $\mathrm{H}_{2} \mathrm{~S}$ - Hydrogen Sulphide, GAS- Gas Production, MOT- Motility, SR- Short Rod, LR (shape)- Long Rod, CC- Cocci Clusters, CP- Cocci Pairs, NA Not Applicable, 


\section{ACKNOWLEDGMENT}

The authors would like to thank University of Maiduguri for nominating the research for sponsorship

\section{COMPETING INTEREST}

The authors declare no competing interest

\section{REFERENCES}

1. Vessey, J. K. (2003) Plant growth promoting rhizobacteria as biofertilizers Kluwer Academic Publishers. Printed in the Netherlands Plant and Soil 255: 571-586.

2. Allamin, I.A.; Yasid, N.A.; Abdullah, S.R.S.; Halmi, M.I.E.; Shukor, M.Y. (2021) Phyto-Tolerance Degradation of Hydrocarbons and Accumulation of Heavy Metals by of Cajanus cajan (Pigeon Pea) in Petroleum-Oily-SludgeContaminated Soil. Agronomy 2021, 11, 1138. https://doi.org/10.3390/ agronomy 11061138

3. Lugtenberg B, Kamilova F (2009) Plant-growth-promoting rhizobacteria. Annu Rev Microbiol 63:541-556

4. Arikan, S. and Pirlak, L. (2016) Effects of Plant Growth Promoting Rhizobacteria (PGPR) on Growth, Yield and Fruit Quality of Sour Cherry (Prunus cerasus L.) Springer-Verlag Berlin Heidelberg

5. Ismail, H.Y., Ijah, U. J. J., Riskuwa, M. L, Allamina, I. A. and Isah, M. A. (2014) Assessment of phytoremediation potentials of legumes in spent engine oil contaminated soil European Journal of Environmental and Safety Sciences 2(2): 59-64.

6. Allamin, I. A., Ijah, U. J. J., Ismail, H. Y. and Riskuwa, M. L. (2014). Occurrence Of Hydrocarbon Degrading Bacteria In Soil In Kukawa, Borno State International Journal Of Environment Volume-3, Issue-2 ISSN 2091-2854.

7. Prescott, L.M., Harley, J.P. and Klein, D.A. (2005) Microbiology. Sixth International Edition. Mcgraw-Hill Publishing Company, UK, 652-668.

8. Bertand, H., Nalin, R., Bally, R., and Cleyet-Marel JC (2001) Isolation and identification of the most efficient plant growthpromoting bacteria associated with canola (Brassica napa). Biol Fertil Soils 33:152-156

9. Kloepper, J.W. (1994) Plant growth promoting bacteria (other systems). In: Okon Y (ed) Azospirillum/plant association. CRC Press, Boca Raton, pp 137-154 